\title{
KEBIJAKAN PENDAPATAN DESA YANG BERSUMBER DARI ALOKASI APBN (DANA DESA) DI INDONESIA MASA REFORMASI 1999-2015 \\ (Studi tentang Perubahan Kebijakan Pendapatan Desa yang Bersumber dari Alokasi APBN/Dana Desa)
}

\author{
VILLAGE REVENUE POLICY SOURCED FROM APBN ALLOCATION (VILLAGE \\ FUND) IN INDONESIA IN THE REFORMATION ERA 1999-2015 \\ (The Study of Changes of Village Revenue Policy Sourced From APBN Allocation \\ /Village Fund)
}

\author{
Rosita Novi Andari \\ Program Magister, Program Studi Kebijakan Publik \\ Program Pascasarjana Fakultas Ilmu Sosial dan Ilmu Politik Universitas Pdjajaran \\ Jl Bukit Dago Utara No. 25 Banfung 40135 \\ rositanovi@gmail.com
}

\begin{abstract}
ABSTRAK
Penelitian ini bertujuan untuk mengkaji bagaimana (isi dan proses) dan mengapa perubahan kebijakan pendapatan desa yang bersumber dari alokasi APBN (Dana Desa) pada masa Reformasi (1999-2015) terjadi. Metode penelitian yang digunakan adalah pendekatan kualitatif dan jenis penelitian deskriptif dengan teknik pengumpulan data melalui studi dokumentasi dan wawancara semi terstuktur, teknik analisis data melalui teknik análisis isi dan teknik analisis interaktif, dan validitas data melalui strategi triangulasi dengan sumber data. Hasil penelitian menunjukkan bahwa perubahan kebijakan pendapatan desa yang bersumber dari alokasi APBN pada masa Reformasi (1999-2015) terjadi pada tingkat perubahan ketiga (perubahan paradigma kebijakan) dari rezim pemerintahan Presiden B.J Habibie dan Presiden Megawati Soekarno Putri melalui konsep bantuan pemerintah dari APBN dengan asas desentralisasi dan keanekaragaman ke rezim pemerintahan Presiden Susilo Bambang Yudhoyono dengan konsep alokasi 10\% dari APBN dengan asas rekognisi dan subsidiaritas. Alasan perubahan kebijakan tersebut antara lain karena adanya: (1) perubahan ide dan kepentingan dari rezim pemerintahan yang berkuasa, (2) peran lembaga pemerintah yaitu Kementrian Dalam Negeri dan DPR sebagai arena instrumen kebijakan, (3) peran individu yaitu Menteri Dalam Negeri, Ketua Panitia Khusus RUU Desa, Ketua Panitia Kerja RUU Desa, dan para staf ahli dari luar DPR sebagai agen utama perubahan kebijakan dan (4) waktu (periode) kejadian mulai dari masa awal reformasi (tahun 1999) hingga tahun 2014 sebagai elemen kunci proses perubahan kebijakan.

Kata kunci: perubahan kebijakan publik, pendapatan desa yang bersumber dari alokasi APBN (Dana Desa)
\end{abstract}

\begin{abstract}
This study aims to examine how (contents and processes) and why to change the village income policy sourced from the APBN allocation (at the Reform Fund) during the Reformation (1999-2015). The research method used is qualitative approach and descriptive research type with data technique and semi structured study, data analysis technique through content analysis and interactive analysis, and data validity through triangulation strategy with data source. The result of the research indicates that the change of village income policy which comes from the allocation of APBN during the Reformation period (1999-2015) occurred at the third level of change (change of policy paradigm) from the government regime of President BJ Habibie and President Megawati Soekarno Putri through the concept of government assistance from APBN with the principle of decentralization and diversity to the government regime of President Susilo Bambang Yudhoyono with the concept of allocation of $10 \%$ of APBN with the principle of recognition and subsidiarity. The reasons for this policy change are: (1) change of ideas and interests of the ruling government regime, (2) the role of government institutions, namely the Ministry of Home Affairs and the House of Representatives as the policy instrument
\end{abstract}


arena, (3) the individual roles of the Minister of Home Affairs, The Special Committee of the Village Bill, the Chairman of the Village Bills Working Committee, and the outside expert staff of the House of Representatives as the main agents of policy change and (4) the time (period) of events from the beginning of the reform period (1999) to 2014 as key elements of the policy change process .

Keywords: changes in public policy, village revenues sourced from APBN (Dana Dana Desa) allocation

\section{A. PENDAHULUAN}

Desa sebagai entitas pemerintahan terendah atau terkecil pada struktur pemerintahan yang diakui secara konstitusional di Negara Kesatuan Republik Indonesia (NKRI)telah mengalami perkembangan yang sangat dinamis seiring dengan perkembangan masa/periode penyelenggaraan pemerintahan di Indonesia. Menurut Hasjimzoem (2014:463) keberadaan pemerintahan desa di Indonesia telah mengalami dinamika tergantung kepada politik hukum pemerintah yang berlaku saat itu dan selalu menjadi pembahasan dalam setiap era pemerintahan dengan berbagai kebijakan yang telah dikeluarkan.

Lebih lanjut menurut Hasjimzoem (2014:468) dinamika perubahan politik hukum pemerintahan desa di Indonesia telah mengalami berbagai macam bentuk sistem pemerintahan dari sistem pemerintahan Orde Lama yang awalnya demokrasi kemudian berubah menjadi otoriter dan pemerintahan Orde Baru yang otoriter yang selanjutnya digantikan oleh Orde Reformasi yang demokratis. Hal ini semua tidak terlepas dari perubahan pola kepemimpinan dalam mengambil kebijakan dimana oleh Mahfud M.D konfigurasi politik yang demokratis akan melahirkan produk hukum yang berkarakter responsif atau otonom sedangkan konfigurasi politik yang otoriter (non demokratis) akan melahirkan produk hukum yang berkarakter konservatif atau ortodoks atau menindas.

Selanjutnya menurut Wahidin (2013:7) pengaruh kekuasaan rezim menjadi salah satu elemen yang mempengaruhi bahkan menentukan pasang surutnya perjalanan otonomi daerah di Indonesia dimana bentuk otonomi daerah berkembang dinamis seiring berjalannya waktu dan berbeda-beda sesuai keinginan rezim yang berkuasa dalam menentukan orientasi dan kepentingannya atas kebijakan administrasi pemerintahan daerah yang diinginkan dan kemudian diaplikasikan. Hal senada dikemukakan oleh Pusat Kajian Politik FISIP UI (2016:33) yang menyatakan bahwa perubahan rezim kebijakan yang mengatur desa bergulir sejalan dengan perubahan semangat dan pemahaman hubungan pemerintahan pusat dan desa yang sebelumnya didominasi oleh pendekatan pembinaan dan mobilisasi kemudian bergerak menjadi pemberdayaan masyarakat desa. Dengan demikian dapat dipahami bahwa perubahan kebijakan mengenai desa tidak terlepas dari pengaruh perubahan politik hukum pemerintahan dan kekuasaan rezim pembuat kebijakan.

Masa reformasi merupakan masa pergantian rezim yang mempengaruhi perubahan kebijakan pemerintahan di Indonesia, khususnya kebijakanmengenai desa. Secara politik, masa reformasi ditandai dengan lengsernya Presiden Soeharto yang memegang jabatan selama 32 tahun dan kemudian diganti oleh Presiden Habibie. Menurut Budiardjo (2015) masa Republik Indonesia IV (1998-sekarang) adalah masa reformasi yang menginginkan tegaknya demokrasi di Indonesia sebagai koreksi terhadap praktik-praktik politik yang terjadi pada masa Republik Indonesia III (1965-1998) dan masa terjadinya empat kali amandemen terhadap UUD 1945 pada tahun 1999-2002 yang mengubah sistem ketatanegaraan Indonesia. Perubahan landasan konstitusional sistem pemerintahan NKRI tersebut selanjutnya memberikan perubahan terhadap arah kebijakan yang mengatur tentang desa di Indonesia dimana secara eksplisit pada pasal 18B ayat(2) amandemen UUD 1945 menyebutkan bahwa negara mengakui dan menghormati kesatuan-kesatuan masyarakat hukum adat beserta hak-hak tradisionalnya sepanjang masih hidup dan sesuai dengan perkembangan masyarakat dan prinsip NKRI yang diatur dalam Undang-Undang (UU). Dengan demikian, dapat diketahui bahwa negara memberikan pengakuan dan jaminan terhadap keberadaan desa melalui pengaturan lebih lanjut dalam UU.

Pada masa reformasi (1999-2015) kebijakan tentang desa mengalami perubahan yang cukup dinamis dibandingkan pada masa pemerintahan sebelumnya yaitu Orde Baru (1965-1998). Pada masa Orde Baru, kebijakan tentang desa yang dikeluarkan oleh pemerintah diatur melalui UU No.5 Tahun 1979 tentang Pemerintahan Desa sebagai satu-satunya kebijakan yang berlaku hingga masa Orde Baru ini berakhir. Sementara itu, pada masa Reformasi kebijakan tentang desa mengalami perubahan sebanyak tiga kali yaitu kebijakan desa yang diatur melalui UU No. 22 Tahun 1999 tentang Pemerintahan Daerah, UU No. 32 Tahun 2004 tentang Pemerintahan Daerah, dan UU No.6 Tahun 2014 tentang Desayang berlaku hingga sekarang. Apabila dibandingkan dengan kedua kebijakan sebelumnya nampak bahwakebijakan tentang desa tidak lagi digabungkan dengan kebijakan tentang pemerintahan daerah, tetapi diatur secara khusus dalam UU yang terpisah pengaturannya dengan pemerintahan daerah. Hal tersebut sebagaimana menurut Yasin dkk (2015:10-12) bahwa pemerintah dan DPR pada proses pembahasan RUU Desa memiliki satu pandangan tentang kegagalan perundang-undangan lama dan pentingnya pengaturan desa melalui undang-undang tersendiri sebagai koreksi terhadap kesalahan-kesalahan aturan lama sekaligus menjadi antisipasi untuk perubahan di masa mendatang serta bentuk penyelarasan dengan konstitusi yaitu penjabaran lebih lanjut pasal 18 ayat (7) dan pasal 18B ayat (2) UUD 1945. Pusat Kajian Politik FISIP UI (2016:67) menilai bahwa UU No.6 
Tahun 2014 merupakan hasil kompromi politik dimana ada dorongan kuat untuk mengubah kebijakan terhadap desa seiring perubahan perpolitikan lokal dari sentralisasi ke desentralisasi. Selanjutnya menurut Hasjimzoem (2014:475) lahirnya UU No.6 tahun 2014 menunjukkan bahwa arah politik hukum pemerintahan desa dari tahun ke tahun telah menuju ke arah yang lebih baik dimana sebagai bagian sistem pemerintahan terkecil, desa telah memiliki peraturannya sendiri.

Salah satu perubahan kebijakan penting dan menjadi perdebatan pada saat proses pembahasan RUU Desa adalah kebijakan yang mengatur tentang pendapatan desa yang bersumber dari alokasi Anggaran Pendapatan dan Belanja Negara (APBN) atau yang kemudian lebih dikenal dengan Dana Desa. Hal tersebut sebagaimana dikemukakan Yasin,dkk (2015:347-348) bahwa dalam proses pembahasan di DPR, perdebatan terbesar ada pada rancangan pasal yang mengatur tentang pendapatan desa, khususnya pasal 72 menjadi pasal yang paling intensif dibahas. Menurut Sutoro Eko yang mengutip pernyataan dari Ketua Pansus RUU Desa bahwa jika UU Desa diperas menjadi satu pasal, maka pasal itu adalah pasal 72 yang berisi sumber-sumber pendapatan desa. Pembahasan mengenai alokasi dari APBN untuk desa menghadapi perbedaan pendapat.

Secara ekplisit kebijakan pendapatan desa yang bersumber dari alokasi APBN (Dana Desa) diatur pada pasal 72 (ayat 1) huruf b UU No. 6 tahun 2014 yang menyebutkan bahwa "pendapatan desa bersumber dari alokasi APBN” dan pada pasal 72 ayat 2 yang menyebutkan bahwa "alokasi anggaran tersebut bersumber dari belanja pusat dengan mengefektifkan program yang berbasis desa secara merata dan berkeadilan”. Lebih lanjut pada penjelasan pasal 72 huruf b yang dimaksud dengan anggaran bersumber dari APBN tersebut adalah anggaran yang diperuntukkan bagi desa dan desa adat yang ditransfer melalui APBD Kabupaten/Kota yang digunakan untuk membiayai penyelenggaraan pemerintahan, pembangunan, serta pemberdayaan masyarakat dan kemasyarakatan. Sedangkan pada penjelasan pasal 72 ayat (2) dinyatakan bahwa besaran alokasi anggaran yang peruntukkannya langsung ke desa ditentukan 10\% (sepuluh persen) dari dan di luar dana transfer daerah (on top) secara bertahap. Anggaran yang bersumber dari APBN dihitung berdasarkan jumlah desa dan dialokasikan dengan memperhatikan jumlah penduduk, angka kemiskinan, luas wilayah, dan tingkat kesulitan geografis dalam rangka meningkatkan kesejahteraan dan pemerataan pembangunan desa. Berdasarkan uraian ketentuan tersebut, maka yang dimaksud dengan kebijakan pendapatan desa yang bersumber dari alokasi APBN (Dana Desa) adalah ketentuan yang mengatur tentang besaran dan cara pengalokasian, penyaluran dan penggunaan pendapatan desa yang bersumber dari alokasi APBN.

Apabila dibandingkan dengan dua kebijakan tentang desa pada UU No.22 Tahun 1999 dan UU No.32
Tahun 2004, maka kedua kebijakan tersebut tidak mengatur secara eksplisit tentang pendapatan desa yang bersumber dari alokasi APBN (Dana Desa) sebagaimana UU No.6 Tahun 2014. Hal ini dapat berarti bahwa selama masa Reformasi telah terjadi perubahan penting pada kebijakan keuangan desa terutama tentang pengaturan pendapatan desa yang bersumber dari alokasi APBN. Sebagaimana dikemukakan Suharto (2016:110) bahwa secara substansial UU No.6 Tahun 2014 memiliki perbedaan signifikan dibanding regulasi-regulasi yang mengatur pemerintahan desa sebelumnya. Di beberapa pasalnya, UU ini berusaha memperkuat kapasitas desa, terutama menyangkut aspek pendanaan. Hal senada juga disampaikan Pusat Kajian Politik FISIP UI (2016:33) bahwa pengalokasian anggaran dana desa dari pemerintah pusat yang diatur pada UU No.6 Tahun 2014 diakui signifikan dan seringkali disebut dan dirujuk sebagai capaian penting bagi desa yang diperoleh dari keluarnya UU tersebut, namun reduksi persoalan UU No. 6 tahun 2014 pada perihal dana desa merupakan penyederhanaan berlebih terhadap kompleksitas kebijakan tersebut yang secara subtantif tersandera antara semangat pembinaan versus pemberdayaan masyarakat desa; serta praktek sentralisasi versus pemenuhan prinsip self-governing di desa.

Dengan demikian dapat dipahami bahwa perubahan kebijakan pendapatan desa yang bersumber dari alokasi APBN(Dana Desa) pada masa Reformasi (1999-2015) merupakan perubahan kebijakan desa yang penting dimana pemerintah pusat secara langsung memberikan jaminan legalitas pembiayaan penyelenggaraan pemerintahan dan pembangunan desa melalui pengaturan pendapatan desa yang bersumber dari APBN pada UU. Implikasi dari perubahan kebijakan pendapatan desa yang bersumber dari alokasi APBN (Dana Desa) adalah terjadinya perubahan mendasar pada APBN. Hal tersebut sebagaimana tertuang pada Nota Keuangan dan APBN Tahun Anggaran 2015 (2015: II.51) bahwa beberapa kebijakan terkait anggaran transfer ke daerah dan Dana Desa mengalami beberapa perubahan mendasar, yaitu pengalokasian Dana Desa dan perubahan postur transfer ke daerah. Jika pada tahun sebelumnya hanya menggunakan nomenklatur transfer ke daerah, mulai tahun 2015 dipergunakan nomenklatur baru, yaitu transfer ke daerah dan Dana Desa. Hal itu merupakan implikasi atas ditetapkannya UU No. 6 Tahun 2014. Berdasarkan UU tersebut maka kepada daerah yang memiliki desa dalam struktur kepemerintahannya akan mendapatkan alokasi dari APBN berupa Dana Desa.

Beberapa hasil penelitian terdahulu yang pernah dilakukan dan dianggap cukup relevan dengan tema tentang kebijakan Dana Desa diantaranya adalah KPK (2015), Pusat Kajian Politik FISIP UI (2016), Abidin (2015), Ismail (2015), Mongilala (2016), Pratiwi dan Roekhudin (2015) dan Aziz (2016), namun demikian semuanya lebih banyak berfokus pada pembahasan tentang berbagai permasalahan implementasi dan evaluasi UU No.6 Tahun 2014 terutama yang berkaitan 
dengan pengelolaan keuangan desa. Adapun dari hasil ketujuh penelitian tersebut dapat diketahui bahwa kebijakan pendapatan desa yang bersumber dari alokasi APBN (Dana Desa) yang ditetapkan melalui UU No.6 Tahun 2014 menghadapi berbagai persoalan antara lain terkait dengan aspek regulasi (pengaturan) dan implementasinya.

Berdasarkan uraian yang dikemukakan dapat diketahui bahwa kebijakan pendapatan desa yang bersumber dari alokasi APBN (Dana Desa) yang diatur pada UU No.6 Tahun 2014 merupakan salah satu perubahan kebijakan desa pada masa Reformasi yang penting dimana berbeda dengan pengaturan sumber pendapatan desa pada UU sebelumnya yaitu UU No.22 Tahun 1999 dan UU No.32 Tahun 2004, mulai tahun 2014 pemerintah pusat secara langsung memberikan jaminan legalitas pembiayaan penyelenggaraan pemerintahan dan pembangunan desa melalui pengaturan tentang besaran dan cara pengalokasian, penyaluran dan penggunaan pendapatan desa yang bersumber dari APBN pada UU. Kebijakan pendapatan desa yang bersumber dari alokasi APBN (Dana Desa) tersebut telah berimplikasi pada adanya perubahan mendasar pada APBN 2015 dan berbagai persoalan terkait aspek regulasi (pengaturan) maupun implementasinya. Oleh karena itu, penelitian tentang perubahan kebijakan pendapatan desa yang bersumber dari alokasi APBN (Dana Desa) pada masa Reformasi di lihat dari sudut pandang ilmu kebijakan publik menjadi penting dilakukan untuk lebih mengkaji salah satu persoalan mendasar yaitu mengapa perubahan kebijakan pendapatan desa yang bersumber dari alokasi APBN (Dana Desa) pada masa Reformasi (1999-2015) terjadi sebagai fokus penelitian. Selain itu, secara akademik, penelitian perubahan kebijakan juga belum banyak dilakukan dimana jika penelitian yang sudah pernah dilakukan sebelumnya cenderung fokus pada studi penelitian cross-sectional (terbatas pada satu waktu) sementara penelitian perubahan kebijakan merupakan studi longitudinal (didasarkan pada masa tertentu yang relative lama) yaitu melihat perubahan kebijakan pendapatan desa yang bersumber dari alokasi APBN (Dana Desa) pada masa Reformasi (1999-2015).

Berdasarkan uraian latar belakang dirumuskan pertanyaan penelitian (research question) sebagai berikut: Mengapa perubahan kebijakan pendapatan desa yang bersumber dari alokasi APBN (Dana Desa) di Indonesia pada Reformasi (1999-2015) terjadi?

\section{B. TINJAUAN PUSTAKA}

Menurut Adrian Kay (2006) dan Pipin Hanapiah (2014) penelitian perubahan kebijakan merupakan penelitian kebijakan dengan analisis model dinamis (analysis dynamic) terhadap kebijakan yang sifatnya temporer dan longitudinal. Perubahan kebijakan publik merupakan bagian tahapan dari proses kebijakan publik. Sebagaimana definisi yang dikemukakan oleh Nugroho (2015), Winarno (2012), Parsons (2011), dan Cerna
(2013) maka yang dimaksud dengan perubahan kebijakan pendapatan desa yang bersumber dari alokasi APBN (Dana Desa) pada penelitian ini adalah perubahan pengaturan tentang pendapatan desa yang bersumber dari alokasi APBN pada kebijakan yang baru muncul yaitu UU No.6 Tahun 2014 sebagai kebijakan baru yang diambil atau hasil revisi kebijakan yang sudah ada sebelumnya yaitu pengaturan tentang sumber pendapatan desa pada UU No. 22 Tahun 1999 dan UU No.32 Tahun 2004.

Selanjutnya untuk mengetahui mengapa perubahan kebijakan pendapatan desa yang bersumber dari alokasi APBN (Dana Desa) di Indonesia pada masa Reformasi maka berdasarkan tiga tingkatan perubahan kebijakan sebagaimana dikemukakan Peter Hall (1993), Padgett (1981), John dan Baumgartner (2005) (dalam Baumgartner, 2013) dan Greener (2002), terlebih dahulu peneliti menganalisis apakah perubahan kebijakan pendapatan desa yang bersumber dari alokasi APBN (Dana Desa) terjadi pada tingkat perubahan kebijakan pertama yaitu perubahan paradigma kebijakan (perubahan ide dasar dan cara pandang dari tujuan kebijakan yang terjadi pada tataran rezim pemerintahan yang berkuasa atau memiliki status quo) atau tingkat perubahan kebijakan kedua yaitu perubahan instrument kebijakan (perubahan cara untuk mencapai tujuan kebijakan yang terjadi pada tataran birokrasi pemerintahan/lembaga/kementrian) ataukah tingkat perubahan ketiga yaitu perubahan rutin kebijakan yang ada (terjadi pada tataran teknis pelaksanaan kebijakan/program). Dari hasil analisis terhadap tiga tingkatan perubahan kebijakan pendapatan desa yang bersumber dari alokasi APBN (Dana Desa) tersebut kemudian peneliti menganalisis alasan terjadinya perubahan kebijakan tersebut dengan mengidentifikasi hal-hal yang menentukan perubahan kebijakan sebagaimana dikemukakan oleh Dudley dan Jeremy (2000) yaitu (1) keterkaitan ide dan kepentingan, (2) peran lembaga sebagai arena instrument kebijakan, (3) peran individu sebagai agen utama perubahan kebijakan, dan (4) waktu sebagai elemen kunci perubahan kebijakan. Dari hasil analisis tersebut kemudian ditarik kesimpulan mengenai alasan-alasan terjadinya perubahan kebijakan pendapatan desa yang bersumber dari alokasi APBN (Dana Desa). Berdasarkan uraian diatas, maka kerangka pemikiran pada penelitian ini dapat dilihat pada gamabr 1 berikut ini: 

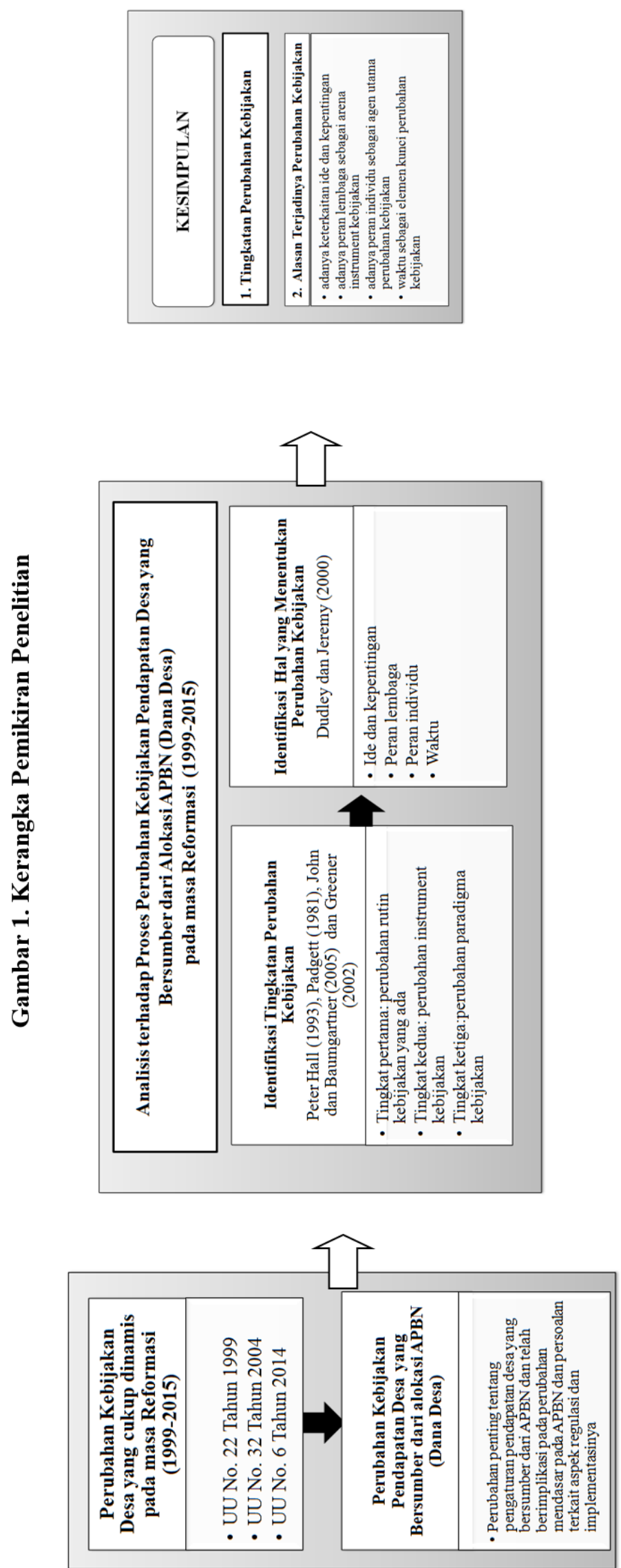


\section{METODE PENELITIAN}

Objek penelitian ini adalah kebijakan pendapatan desa yang bersumber dari alokasi APBN (Dana Desa) di Indonesia pada masa Reformasi (1999-2015) yang diatur pada pada Undang-Undang No. 22 Tahun 1999, UndangUndang No. 32 Tahun 2004 dan Undang-Undang No.6 Tahun 2014. Penentuan objek penelitian ini didasari fakta bahwa perubahan kebijakan tentang pendapatan desa yang bersumber dari alokasi APBN pada masa Reformasi terjadi pada skala kebijakan level nasional dan masa reformasi (1999-2015) adalah periode waktu yang dijadikan acuan studi perubahan kebijakan dalam jangka panjang (longterm/longitudinal) sebagaimana dikemukakan oleh Adrian Kay (2006) dan Pipin Hanapiah (2014).

Informasi mendalam tentang objek penelitian diatas, pada pelaksanaannya dilakukan di tingkat lembaga legislatif (DPR RI) dan tingkat lembaga eksekutif birokrasi pemerintahan (Kementrian Dalam Negeri) yang memiliki peran utama dalam proses dalam proses perumusan UU No.22 Tahun 1999, UU No.32 Tahun 2004 dan UU No. 6 Tahun 2014. DPR RI adalah lembaga legislatif yang memiliki kewenangan dalam perumusan UU sementara Kementrian Dalam Negeri adalah kementrian teknis yang memiliki kewenangan dalam penyusunan kebijakan tentang pemerintahan desa dan ditunjuk oleh Presiden sebagai wakil pemerintah dalam proses pembahasan UU di tingkat legislatif.

Pendekatan penelitian yang digunakan dalam penelitian ini adalah pendekatan penelitian kualitatif dan jenis penelitian deskripsi dengan dasar pertimbangan pemilihan pendekatan kualitatif dengan jenis penelitian deskriptif karena dianggap cocok untuk mengungkap secara mendalam terkait pertanyaan mengapa dan bagaimana terjadinya perubahan kebijakan pendapatan desa yang bersumber dari alokasi APBN (Dana Desa) di Indonesia pada masa Reformasi (1999-2015). Penelitian ini berusaha mengungkap pandangan, sikap, dan pengalaman informan di lembaga legislatif dan eksekutif yang terlibat dalam penyusunan kebijakan pendapatan desa yang bersumber dari alokasi APBN (Dana Desa) tentang mengapa dan bagaimana perubahan kebijakan Dana Desa pada masa Reformasi terjadi.

Teknik pengumpulan data yang digunakan pada penelitian ini adalah studi dokumentasi dilakukan untuk mengumpulkan dan menggali data sekunder berupa dokumen publik yang menurut Creswell (2016:255) seperti: dokumen kebijakan, laporan instansi, laporan penelitian. Data sekunder diperoleh dari instansi pemerintah yaitu DPR RI, Direktorat Jenderal Bina Pemerintahan Desa (Kementrian Dalam Negeri), Direktorat Jenderal Pembangunan dan Pemberdayaan Masyarakat Desa (Kementrian Desa, Pembangunan Daerah Tertinggal, dan Transmigrasi), dan Kementrian Keuangan, website dan lain-lainnya serta sejumlah dokumen berupa laporan dan publikasi lain yang dihasilkan oleh pihak/lembaga lain yang ada kaitannya dengan masalah penelitian. Selain itu, dengan wawancara dilakukan untuk mengumpulkan data primer dari informan penelitian yang berkaitan dengan masalah penelitian. Informan dipilih secara purposive yakni dilakukan dengan memilih individu-individu dan tempat untuk diteliti karena mereka dapat secara spesifik memberi pemahaman tentang problem riset dan fenomena dalam studi tersebut sebagaimana dikemukakan Creswell (2015:220). Informan pada penelitian ini adalah individu yang mengetahui informasi tentang perubahan kebijakan pendapatan desa yang bersumber dari alokasi APBN (Dana Desa) pada masa Reformasi (1999-2015) dan dipilih secara berantai tergantung data yang dikumpulkan yaitu: (1) Ketua Panitia Khusus RUU Desa (DPR RI), (2) Staf ahli DPR RI yang terlibat pada perumusan UU Desa, (3) Anggota Tim Panja Pemerintah (Kementrian Dalam Negeri), (4) Pengamat Kebijakan Keuangan Desa dari IPDN. Adapun teknik pengumpulan data lapangan dilakukan dengan wawancara semi terstruktur dimana peneliti telah menyiapkan intrumen penelitian berupa pedoman wawancara namun dalam pelaksanaanya pewawancara tidak mengatur proses wawancara secara sistematis dikarenakan waktu yang terbatas.

Analisis data dalam penelitian ini dilakukan melalui dua cara yaitu teknik analisis isi (content analysis) sebagaimana dikemukakan oleh Bungin (2014:167) dan Nugraheni (2009:130) dan teknik analisis interaktif sebagaimana dikemukakan oleh Silalahi (2009:339-341). Analisis isi yang dilakukan pada penelitian ini adalah dengan menganalisis isi dokumen kebijakan yang berkaitan dengan kebijakan dana desa. Sedangkan analisis data interaktif pada penelitian ini dilakukan untuk membantu menganalisis proses dan alasan terjadinya perubahan kebijakan dana desa. Selanjutnya, validitas data pada penelitian ini dilakukan strategi triangulasi dengan sumber data sebagaimana dikemukakan oleh Creswell (2016:347-349) dan Bungin (2014: 264-265) yaitu dengan membandingkan dan mengecek baik derajat kepercayaan suatu informasi yang diperoleh dari isi dokumen kebijakan desa dan hasil wawancara yang berkaitan.

\section{HASIL PENELITIAN}

Perubahan kebijakan pendapatan desa yang bersumber dari alokasi APBN (Dana Desa) pada penelitian ini adalah perubahan pengaturan tentang sumber pendapatan desa yang berasal dari alokasi APBN pada kebijakan yang baru muncul yaitu UU No.6 Tahun 2014 sebagai kebijakan baru yang diambil atau hasil revisi kebijakan yang sudah ada sebelumnya yaitu pengaturan tentang sumber pendapatan desa pada UU N,o. 22 Tahun 1999 dan UU No.32 Tahun 2004. Analisis dinamis pada penelitian perubahan kebijakan pendapatan desa yang bersumber dari alokasi APBN (Dana Desa) pada masa Reformasi (1999-2015) ini difokuskan pada dinamika kebijakan yang terletak pada perumusan kebijakan tersebut sebagaimana dikemukakan oleh Adrian Kay (2006). Oleh karena itu, untuk mengetahui 
mengapa perubahan kebijakan pendapatan desa yang bersumber dari alokasi APBN (Dana Desa) pada masa Reformasi (1999-2015) terjadi, maka peneliti terlebih dahulu menganalisis proses perubahan kebijakan dengan mengidentifikasi tingkatan perubahan kebijakan dan kemudian mengidentifikasi hal-hal yang menentukan perubahan kebijakan tersebut pada saat kebijakan tersebut dirumuskan pada tahun 1999 melalui UU No.22 Tahun 1999 kemudian pada tahun 2004 melalui UU No.32 Tahun 2004 dan pada tahun 2014 melalui UU No.6 Tahun 2014.

\section{Analisis Tingkatan Perubahan Kebijakan Pendapatan Desa yang bersumber dari alokasi APBN (Dana Desa) pada masa Reformasi (1999- 2015)}

Berdasarkan isi ketentuan yang berkaitan dengan pendapatan desa yang bersumber dari alokasi APBN (Dana Desa) dari UU No. 22 Tahun 1999, UU No.32 Tahun 2004 dan UU No.6 Tahun 2014 dapat diketahui bahwa telah terjadi perubahan isi kebijakan sumber pendapatan desa yang diatur dari UU No.22 Tahun 1999 hingga UU No.6 Tahun 2014 dimana jika pada UU No.22 Tahun 1999 dan UU No.32 Tahun 2004 tidak ada pasal yang secara eksplisit mengatur ketentuan mengenai pendapatan desa yang bersumber dari alokasi APBN, maka pada UU No. 6 Tahun 2014 ketentuan tersebut diatur secara eksplisit dan jelas pada pasal 72 ayat 1 huruf (b) dan ayat 2 yaitu bahwa pendapatan desa yang bersumber dari alokasi APBN adalah anggaran yang diperuntukkan bagi desa dan desa adat yang ditransfer melalui anggaran pendapatan dan belanja daerah kabupaten/kota yang digunakan untuk membiayai penyelenggaraan pemerintahan, pembangunan, serta pemberdayaan masyarakat dan kemasyarakatan. Alokasi anggaran tersebut bersumber dari Belanja Pusat dengan mengefektifkan program yang berbasis desa secara merata dan berkeadilan dengan besaran alokasi anggaran yang peruntukannya langsung ke desa ditentukan $10 \%$ (sepuluh perseratus) dari dan di luar dana transfer daerah (on top) secara bertahap dan dihitung berdasarkan jumlah Desa dan dialokasikan dengan memperhatikan jumlah penduduk, angka kemiskinan, luas wilayah, dan tingkat kesulitan geografis dalam rangka meningkatkan kesejahteraan dan pemerataan pembangunan Desa. Dari ketentuan tersebut nampak jelas bahwa tujuan kebijakan pendapatan desa yang bersumber dari alokasi APBN adalah pemerintah memberikan alokasi anggaran dari APBN sebesar $10 \%$ kepada desa untuk membiayai penyelenggaraan pemerintahan, pembangunan serta pemberdayaan masyarakat dan kemasyarakatan di desa.

Sementara itu, pada UU No.22 Tahun 1999 tidak nampak jelas tujuan kebijakan pendapatan desa yang bersumber dari APBN sebagaimana UU No.6 Tahun 2014. Sedangkan pada UU No.32 Tahun 2004 sekalipun ada pasal yang mengatur tentang pendapatan desa yang bersumber dari APBN dalam bentuk bantuan keuangan pemerintah namun tidak nampak jelas tujuan dari kebijakan tersebut. Dengan demikian, dapat diketahui bahwa telah terjadi perubahan dalam tujuan kebijakan pendapatan desa yang bersumber dari APBN yang diatur pada UU No.22 Tahun 1999, UU No.32 Tahun 2004 dan UU No.6 Tahun 2014. Apabila dilihat dari tingkatan perubahan kebijakan, maka perubahan tujuan kebijakan yang terjadi pada kebijakan di tingkat pusat atau Presiden dalam bentuk UU adalah termasuk perubahan kebijakan tingkat ketiga yaitu perubahan paradigma kebijakan.

Selanjutnya apabila terjadi perubahan kebijakan pada tingkat ketiga (perubahan paradigma kebijakan), maka diikuti juga dengan adanya perubahan kebijakan pada tingkat kedua (perubahan instrument kebijakan) dan perubahan kebijakan pada tingkat ketiga yaitu perubahan teknis pelaksanaan kebijakan. Perubahan kebijakan tingkat kedua atau perubahan instrument kebijakan pendapatan desa yang bersumber dari alokasi APBN adalah perubahan cara untuk mencapai tujuan kebijakan yang terjadi pada tataran birokrasi pemerintahan/lembaga/kementrian. Perubahan ini dapat diidentifikasi dari analisis isi kebijakan turunan dari UU No.22 Tahun 1999, UU No.32 Tahun 2004, dan UU No.6 Tahun 2014 dalam bentuk Peraturan Pemerintah (PP). Adapun kebijakan turunan dari UU No.22 Tahun 1999 adalah PP No. 76 Tahun 2001 tentang Pedoman Umum Pengaturan Mengenai Desa. Sedangkan kebijakan turunan pemerintah dari UU No.32 Tahun 2004 adalah PP No.72 Tahun 2005 tentang Desa. Sementara itu, kebijakan turunan pemerintah dari UU No.6 Tahun 2014 adalah PP No. 43 Tahun 2014 tentang Peraturan Pelaksanaan UU No.6 Tahun 2004 tentang Desa dan perubahannya pada PP No.47 Tahun 2015. Selain itu juga ada PP yang mengatur tentang pendapatan desa yang bersumber dari alokasi APBN secara khusus yaitu PP No.60 Tahun 2014 tentang Dana Desa yang Bersumber dari APBN dan perubahannya pada PP No.22 Tahun 2015.

Dari perubahan isi instrumen kebijakan dari UU No.22 Tahun 1999, UU No.32 Tahun 2004, dan UU No.6 Tahun 2014 dalam bentuk Peraturan Pemerintah tersebut dapat diketahui bahwa telah terjadi perubahan cara untuk mencapai tujuan kebijakan pendapatan desa yang bersumber dari alokasi APBN yang terjadi pada tataran birokrasi pemerintahan/lembaga/kementrian dimana pada PP No.43 Tahun 2001 dan PP No.72 Tahun 2005 tidak ada ketentuan yang secara khusus mengatur tentang besaran dan cara pengalokasian, penyaluran dan penggunaan pendapatan desa yang bersumber dari alokasi APBN sebagaimana PP turunan dari UU No.6 Tahun 2014. Ketentuan yang ada pada PP No.43 Tahun 2001 menunjukkan bahwa ada sumber pendapatan desa dari pemerintah dalam bentuk bantuan dari pemerintah tetapi tidak jelas ketentuan besaran dan cara pengalokasian, penyaluran dan penggunaannya apakah bersumber dari alokasi APBN ataukah tidak. Kemudian. ketentuan yang ada pada PP No.72 Tahun 2005 menunjukkan bahwa ada ketentuan umum tentang 
keuangan desa yang mengatur bahwa penyelenggaraan urusan pemerintah yang diselenggarakan oleh pemerintah desa didanai dari APBN, namun tidak ada penjelasan lebih lanjut tentang besaran dan cara pengalokasian, penyaluran dan penggunaan dana APBN tersebut dalam penyelenggaraan urusan pemerintah. Selain itu, ada sumber pendapatan desa dari pemerintah dalam bentuk bantuan pemerintah yang penggunaannya diutamakan untuk tunjangan kepala desa dan perangkat desa, tetapi tidak jelas mengenai ketentuan besaran dan cara pengalokasian dan penyalurannya apakah bersumber dari alokasi APBN ataukah tidak. Adapun pada PP No.43 Tahun 2014 dan perubahannya pada PP No.47 Tahun 2015 diatur ketentuan umum tentang penyebutan Dana Desa sebagai dana yang bersumber dari alokasi APBN yang kemudian ketentuan rinci tentang besaran dan cara pengalokasian, penyaluran dan penggunaan pendapatan desa yang bersumber dari alokasi APBN diatur pada PP No.60 Tahun 2014 dan perubahannya pada PP No.22 Tahun 2015. Dengan demikian dapat diketahui bahwa perubahan kebijakan pendapatan desa yang bersumber dari alokasi APBN juga terjadi pada tingkat perubahan kebijakan kedua yaitu perubahan instrument kebijakan.

Selanjutnya perubahan kebijakan tingkat ketiga yaitu perubahan rutin kebijakan yang ada dan terjadi pada tataran teknis pelaksanaan kebijakan/program yang berkaitan dengan pendapatan desa yang bersumber dari APBN dapat diidentifikasi dari analisis isi pedoman teknis pelaksanaan kebijakan tersebut yaitu dalam bentuk Peraturan Menteri. Kebijakan teknis pelaksanaan UU No.22 Tahun 1999 mengenai sumber pendapatan desa tidak ada yang ditetapkan pemerintah dalam bentuk Peraturan Menteri. Hal tersebut sebagaimana diatur pada PP No.76 Tahun 2001 bahwa ketentuan lebih lanjut mengenai sumber pendapatan desa ditetapkan dalam peraturan daerah kabupaten. Kemudian kebijakan teknis pelaksanaan UU No.32 Tahun 2004 mengenai sumber pendapatan desa tidak ada yang ditetapkan pemerintah dalam bentuk Peraturan Menteri. Hal tersebut sebagaimana diatur pada PP No.72 Tahun 2005 bahwa ketentuan lebih lanjut mengenai sumber pendapatan desa diatur dengan peraturan daerah kabupaten/kota yang muatannya berpedoman pada PP tersebut. Selanjutnya kebijakan teknis pelaksanaan UU No.6 Tahun 2014 mengenai pendapatan desa yang bersumber dari alokasi APBN sebagaimana diatur pada PP No.60 Tahun 2014 adalah Peraturan Menteri Keuangan No.93/PMK.07/2015 tentang Tata Cara Pengalokasian, Penyaluran, Penggunaan, Pemantauan, dan Evaluasi Dana Desa dan Peraturan Menteri Desa, PDT, dan Transmigrasi No.5 Tahun 2015 tentang Penetapan Prioritas Penggunaan Dana Desa Tahun 2015

Dari hasil analisis isi perubahan teknis pelaksanaan kebijakan dari UU No.22 Tahun 1999, UU No.32 Tahun 2004, dan UU No.6 Tahun 2014 sebagaimana tabel 4.8 dapat diketahui bahwa telah terjadi perubahan kebijakan pada tataran teknis pelaksanaan kebijakan pendapatan desa yang bersumber dari APBN dimana teknis pelaksanaan kebijakan pendapatan desa dari UU No.22 Tahun 1999 dan UU No.32 Tahun 2004 yang berkaitan dengan ketentuan mengenai besaran dan cara pengalokasian, penyaluran dan penggunaan pendapatan desa dari sumber manapun sebagaimana yang telah ditentukan oleh UU (termasuk didalamnya bantuan pemerintah) menjadi kewenangan dari setiap kabupaten/kota untuk mengaturnya, sehingga dapat diasumsikan isi dari Peraturan Daerah yang ditetapkan oleh setiap kabupaten/kota berbeda satu dengan yang lainnya tergantung dari komitmen masing-masing kabupaten/kota. Selanjutnya teknis pelaksanaan kebijakan dari UU No.6 Tahun 2014 sudah mengatur secara rinci dan jelas mengenai besaran dan cara pengalokasian, penyaluran dan penggunaan pendapatan desa. Dengan demikian dapat diketahui bahwa perubahan kebijakan pendapatan desa yang bersumber dari alokasi APBN juga terjadi pada tingkat perubahan kebijakan ketiga yaitu perubahan teknis pelaksanaan kebijakan.

Berdasarkan hasil analisis tingkatan perubahan kebijakan pendapatan desa yang bersumber dari alokasi APBN pada masa Reformasi (1999-2015) dapat diketahui bahwa perubahan kebijakan tersebut terjadi pada tingkatan perubahan kebijakan ketiga yaitu perubahan paradigma kebijakan yang ditandai dengan adanya perubahan cara pandang terhadap tujuan kebijakan dari rezim pemerintahan yang berkuasa mulai dari rezim pemerintahan Presiden B.J Habibie, Presiden Megawati Soekarnoputri dan Presiden Susilo Bambang Yudhoyono. Selain itu, perubahan paradigma kebijakan tersebut juga dengan adanya perubahan kebijakan pada tingkat kedua (perubahan instrumen kebijakan) dan tingkat ketiga (perubahan teknis pelaksanaan kebijakan).

\section{Analisis Hal-Hal yang Menentukan Perubahan Kebijakan Pendapatan Desa yang bersumber dari alokasi APBN (Dana Desa) pada masa Reformasi (1999-2015)}

Untuk mengetahui mengapa terjadi perubahan kebijakan pendapatan desa yang bersumber dari alokasi APBN pada tingkatan ketiga (perubahan paradigma kebijakan) maka peneliti mengidentifikasi empat hal yang menentukan perubahan kebijakan sebagaimana dikemukakan oleh Duddle dan Jeremy (2000) yaitu sebagai berikut:

\section{Keterkaitan Ide-Ide dan Kepentingan}

Berdasarkan hasil analisis dokumen perumusan UU No.22 Tahun 1999, UU No. 32 Tahun 2004 dan UU No.6 Tahun 2014 serta hasil wawancara dengan narasumber penelitian dapat diketahui evolusi perubahan ide-ide kebijakan pendapatan desa yang bersumber dari APBN pada UU No.22 Tahun 1999 hingga UU No.6 Tahun 2014 berkaitan erat dengan perubahan kepentingan-kepentingan dari berbagai pihak terutama pemerintah (Presiden dan jajarannya) dengan DPR selaku lembaga legislatif terhadap keberdaan desa dalam konteks penyelenggaraan pemerintahan dan 
pembangunan. Ide-ide kebijakan pendapatan desa yang bersumber dari alokasi APBN nampak belum menjadi fokus perhatian dari masa pemerintahan pada waktu yaitu pemerintahan Presiden B.J Habibie dan Presiden Megawati Soekarno Putri sehingga kebijakan sumber pendapatan desa secara substansi tidak memiliki banyak perubahan yang signifikan apabila dibandingkan dengan kebijakan sebelumnya yaitu UU No.5 Tahun 1979 seperti kebijakan sumber pendapatan desa dengan konsep "bantuan pemerintah" sekalipun pada UU No.32 Tahun 2004 sudah lebih jelas pengaturannya. Sementara itu, pada UU No. 6 Tahun 2014 ide-ide kebijakan pendapatan desa yang bersumber dari alokasi APBN nampak menjadi fokus utama pada masa pemerintahan Presiden Susilo Bambang Yudhoyono dimana ide-ide tersebut cenderung berkembang sangat dinamis mulai dari munculnya ide tersebut dari asosiasi atau perhimpunan atau komunitas elemen pemerintahan dan masyarakat desa hingga masuk ke proses pembahasan RUU Desa di tingkat legislatif.

Dari keseluruhan proses perubahan ide-ide kebijakan sumber pendapatan desa pada UU No. 22 Tahun 1999 hingga UU No.6 Tahun 2014, nampak adanya perubahan kepentingan dari berbagai pihak terutama pemerintah (Presiden dan jajarannya) dengan DPR selaku lembaga legislatif terhadap keberdaan desa dalam konteks penyelenggaraan pemerintahan dan pembangunan. Pada UU No.22 Tahun 1999 dan UU No.32 Tahun 2004, pemerintah dan DPR cenderung sepakat bahwa desa dijadikan sebagai objek pembangunan dan landasan kebijakan sumber pendapatan desa lebih menekankan pada asas desentralisasi dan keanekaragaman sehingga pengaturannya diserahkan kepada masing-masing kabupaten sesuai kondisi masing-masing desa sehingga pemberian dana sangat tergantung dari pemerintahan diatasnya baik pemerintah maupun pemerintah daerah. Adapun sumber pendapatan desa dengan konsep "bantuan pemerintah” nampak tidak memiliki dasar asas yang jelas. Sementara itu, pada UU No. 6 Tahun 2014 pemerintah dan DPR sepakat bahwa desa dijadikan sebagai subyek pembangunan sehingga pemerintah wajib memberikan alokasi dana dari APBN sebesar $10 \%$ dari dan di luar dana transfer daerah secara bertahap (on top) kepada desa yang ditujukan untuk membiayai penyelenggaraan pemerintahan, pembangunan serta pemberdayaan masyarakat dan kemasyarakatan di desa. Landasan kebijakan sumber pendapatan desa dari APBN tersebut adalah asas rekognisi dan subsidiaritas.

Selain itu, jika pada UU No.22 Tahun 1999 dan UU No.32 Tahun 2004, kepentingan individu, partai politik, lembaga pemerintah dan pemerintah kabupaten dan pemerintah desa terhadap kebijakan sumber pendapatan tidak nampak jelas, maka pada UU No.6 Tahun 2014, beberapa kepentingan yang nampak dari awal hingga akhir perumusan kebijakan tersebut diputuskan antara lain:

a. Adanya kepentingan dari beberapa anggota legislatif agar dirinya maupun partai politiknya dipilih kembali pada saat pemilu 2014 yang dapat dilihat dari kampanye-kampanye terutama pada saat RDPU dengan para kepala desa dan perangkat desa dan Rapat Paripurna.

b. Adanya kepentingan dari pemerintah (Presiden SBY) yang semula tidak menyetujui pada akhirnya menyetujui dengan berbagai pertimbangan salah satunya adalah bahwa lahirnya UU Desa sebagai hasil diakhir masa pemerintahan Presiden SBY.

2. Peran lembaga sebagai arena instrumen kebijakan

Lembaga pemerintah yang memiliki peran dominan pada perubahan kebijakan pendapatan desa yang bersumber dari alokasi APBN adalah DPR sebagai lembaga legislatif dan Kementrian Dalam Negeri sebagai wakil dari pemerintah (lembaga eksekutif).

Peran DPR sebagai lembaga legislatif adalah menterjemahkan setiap ide-ide kebijakan yang disampaikan baik oleh pemerintah maupun oleh berbagai organisasi atau asosiasi atau perhimpunan pemerintah, lembaga penelitian dan para pakar dan akademisi di luar pemerintah menjadi berbagai alternatif kebijakan yang kemudian dirumuskan ke dalam norma pasal pada RUU sampai disahkan menjadi UU sehingga memiliki legalitas untuk dilaksanakan. Terdapat perbedaan peran DPR sebagai lembaga legislatif ketika merumuskan kebijakan pendapatan desa yang bersumber dari APBN dalam bentuk bantuan pemerintah pada UU No.22 Tahun 1999 dan UU No.32 Tahun 2004 dengan ketika merumuskan kebijakan pendapatan desa yang bersumber dari alokasi APBN pada UU No.6 Tahun 2014. Perbedaan peran tersebut adalah jika pada UU No.22 Tahun 1999 dan UU No.32 Tahun 2004, peran DPR nampak tidak terlalu dominan dalam menggiring ide-ide kebijakan menjadi alternatif kebijakan dan keputusan kebijakan karena DPR cenderung menyetujui ide-ide kebijakan yang diusulkan oleh pemerintah melalui Kementrian Dalam negeri, maka pada UU No.6 Tahun 2014 peran DPR nampak lebih dominan. DPR mampu menggiring ide-ide kebijakan menjadi alternatif kebijakan dan keputusan politik bersama dengan pemerintah karena ide-ide kebijakan lebih banyak diusulkan oleh DPR dan bahkan DPR memiliki pengaruh sangat kuat yang mendorong pemerintah (presiden) pada akhirnya menyetujui keputusan DPR atas kebijakan tersebut. Hal tersebut antara lain nampak dari rumusan pasal yang diputuskan oleh DPR mengenai besaran alokasi APBN sebesar $10 \%$ yang pada akhirnya disetujui oleh pemerintah.

Selain DPR, Kementrian Dalam Negeri adalah wakil dari pemerintah (Presiden) selaku lembaga eksekutif yang juga memiliki peran penting pada perubahan kebijakan pendapatan desa yang bersumber dari APBN. Pada UU No.22 Tahun 1999 dan UU No.32 Tahun 2004, Kementrian Dalam Negeri (Departemen Dalam Negeri) memiliki peran yang sangat dominan dalam menggiring ide-ide kebijakan tersebut menjadi keputusan politik yang disetujui oleh DPR tanpa melalui perdebatan yang alot dan tarik menarik kepentingan. Selanjutnya pada UU No.6 Tahun 2014, Kementrian 
Dalam Negeri juga memiliki peran yang dominan seperti DPR bahkan bisa dijadikan lembaga penentu dari keputusan Presiden hingga akhirnya menyetujui kebijakan pendapatan desa yang bersumber dari alokasi APBN pada UU. Hal tersebut antara lain nampak pada saat perdebatan antara DPR dan pemerintah (Kementrian Dalam Negeri) pada saat Rapat Pansus tanggal 11 Desember 2013 mengenai penjelasan besaran alokasi anggaran yang peruntukannya langsung ke desa ditentukan $10 \%$ dari dan diluar dana transfer daerah (tidak bertahap) atau secara bertahap.

Menurut staf ahli $\mathrm{DPR}^{1}$ pada saat pembahasan RUU Desa, debat yang paling panjang adalah terkait rumusan di pasal 72 itu dan yang membuat rumusan pasal 72 itu jadi (disetujui), sebenarnya ada "main mata” antara Ketua Pansus dan Kemendagri, sekalipun Bappenas dan Kementrian Keuangan menolak tetapi karena Presiden mempercayakan satu orang satu pintu yaitu Tim Panitia Kerjanya pemerintah yang diketuai oleh Kemendagri. Pada proses politiknya ada saling konsolidasi antara tim pemerintah dan DPR, antar pimpinan Partai hingga adanya gerakan-gerakan dari para kepala desa yang datang ke DPR.

Di samping peran dalam proses perumusan kebijakan tersebut pada UU, Kementrian Dalam Negeri juga memiliki peran penting dalam menindaklanjuti pelaksanaan kebijakan tersebut antara lain membuat Peraturan Pemerintah atau aturan turunan sehingga dapat segera dilaksanakan dan melakukan sosialisasi, pembinaan, pelatihan keuangan desa kepada Kepala Desa, dan pengawasan terhadap pelaksanaan kebijakan tersebut sesuai dengan tujuan kebijakan yang telah ditetapkan.

Selain Kementrian Dalam Negeri, Kementrian Keuangan juga memiliki peran yang penting sebagai arena instrument kebijakan. Sejak ide-ide kebijakan pendapatan desa yang bersumber dari alokasi APBN muncul, Kementrian Keuangan termasuk lembaga pemerintah yang nampak menolak usulan tersebut dengan berbagai pertimbangan. Namun demikian, pada akhirnya Kementrian Keuangan pada saat proses pembahasan kebijakan tersebut cenderung memberikan pandangan yang mendukung ide kebijakan tersebut.

3. Peran Individu sebagai Agen Utama Perubahan Kebijakan

Perubahan kebijakan pendapatan desa yang bersumber dari alokasi APBN ditentukan oleh peran dari individu sebagai agen utama perubahan khususnya melalui kemampuan mereka untuk menyampaikan dan mengirimkan ide-ide baru ke dalam inti dari sektor kebijakan. Peran individu tersebut juga dapat memperkuat tindakan kolektif dan memperluas nilainilai dan dasar kepentingan organisasi atau lembaga mereka pada saat pengambilan keputusan atas kebijakan tersebut.

\footnotetext{
${ }^{1}$ Hasil wawan cara tanggal 4 Mei 2017
}

Pada UU No.22 Tahun 1999 dan UU No.32 Tahun 2004 tidak banyak individu yang memiliki peran menonjol pada proses perumusan kebijakan sumber pendapatan desa baik dari DPR maupun pemerintah. Menteri Dalam Negeri adalah individu yang nampak paling menonjol sebagai agen utama perubahan kebijakan tersebut. Pada UU No.22 Tahun 1999, H. Syarwan Hamid selaku Menteri Dalam Negeri adalah individu yang dapat dianggap memiliki peran penting karena ditunjuk oleh Presiden B.J Habibie sebagai wakil pemerintah untuk menyusun RUU tentang Pemerintahan Daerah untuk kemudian menyerahkan dan membahasnya secara bersama dengan DPR. Secara umum ide-ide kebijakan sumber pendapatan desa terutama bantuan pemerintah yang disampaikan oleh Menteri Dalam Negeri tidak mendapatkan penolakan dari para anggota legislatif dari empat fraksi di DPR yaitu Fraksi Persatuan Pembangunan (FPP), Fraksi Karya Pembangunan (FKP), Fraksi ABRI (FABRI), dan Fraksi Partai Demokrasi Indonesia (FPDI). Hal tersebut nampak dari rumusan pasal tentang sumber pendapatan desa yang berbentuk bantuan dari pemerintah tersebut disetujui tetap tanpa perubahan apapun oleh seluruh anggota DPR sejak awal draft RUU hingga disahkan menjadi UU.

Sementara itu, pada UU No.32 Tahun 2004, Oentarto Sindung Mawardi (Direktur Jenderal Otonomi Daerah, Departemen Dalam Negeri) adalah individu yang nampak berperan sebagai agen utama perubahan kebijakan desa karena menjadi wakil dari pemerintah (Presiden Megawati Soekarno Putri dan Menteri Dalam Negeri) yang menyampaikan ide-ide kebijakan sumber pendapatan desa dan membahasnya secara bersama dengan DPR. Secara umum ide-ide kebijakan sumber pendapatan desa terutama bantuan pemerintah yang disampaikan oleh Dirjen Otda adalah bahwa pada dasarnya tidak perubahan pengaturan secara signifikan dari UU No.22 Tahun 1999 yaitu dengan rumusan pasal yang lebih diperjelas lagi terutama dalam pengertian agar pemerintah kabupaten tidak menyusun peraturan daerah sesuka hati tanpa ada acuan dan pedoman yang jelas dari pemerintah. Adapun penjelasan dari rumusan pasal tentang sumber pendapatan desa dari bantuan keuangan pemerintah adalah bantuan yang bersumber dari APBN. Usulan tersebut kemudian disepakati dan disetujui oleh para anggota legislatif dari sembilan fraksi di DPR yaitu Fraksi Partai Persatuan Pembangunan (FPPP), Fraksi Partai Golkar (FPG), Fraksi Partai Demokrasi Indonesia Perjuangan (FPDI-P), Fraksi Kebangkitan Bangsa (FKB), Fraksi Partai Bulan Bintang (FPBB), Fraksi Kesatuan Bangsa Indonesia (FKBI), Fraksi Perserikatan Daulatul Ummah (FPDU), Fraksi TNI/Polri, dan Fraksi Reformasi.

Berbeda dengan dua kebijakan sebelumnya, pada UU No.6 Tahun 2014, terdapat beberapa individu yang nampak sangat berperan sebagai agen utama perubahan kebijakan pendapatan desa yang bersumber dari alokasi 
APBN khususnya melalui kemampuan mereka untuk menyampaikan dan mengirimkan ide-ide kebijakan baik dari lembaga DPR maupun pemerintah antara lain:

Pertama, Gamawan Fauzi selaku Menteri Dalam Negeri adalah individu dari lembaga pemerintah yang nampak sangat berperan sebagai agen utama perubahan kebijakan pendapatan desa yang bersumber dari alokasi APBN karena menjadi wakil dari pemerintah (Presiden Susilo Bambang Yudhoyono) untuk menyampaikan ideide kebijakan sumber pendapatan desa dan membahasnya secara bersama dengan para anggota DPR. Pada saat pembahasan kebijakan tersebut, Gamawan Fauzi selalu hadir pada setiap rapat kerja dengan DPR dan mempengaruhi setiap pengambilan keputusan yang dilakukan oleh DPR dan juga Presiden atas kebijakan tersebut. Kedua, Drs. Ahmad Muqowam selaku Ketua Pansus RUU Desa adalah juga individu dari lembaga DPR dari F-PPP juga berperan sebagai agen utama perubahan kebijakan yang bersumber dari alokasi APBN pada UU No.6 Tahun 2014. Selain memimpin jalannya setiap rapat kerja pembahasan kebijakan tersebut dengan pemerintah, Ketua Pansus juga berperan dalam menyampaikan ide-ide kebijakan yang mempengaruhi pandangan setiap anggota DPR yang lain baik internal FPPP maupun fraksi lain di DPR serta pemerintah (Menteri Dalam Negeri). Ketiga, Budiman Sudjatmiko M.Sc., M.Phil (F-PDI P) selaku Ketua Panja adalah juga individu dari lembaga DPR dari F-PPP juga berperan sebagai agen utama perubahan kebijakan yang bersumber dari alokasi APBN pada UU No.6 Tahun 2014. Ketua Panja berperan dalam proses perumusan dan sikronisasi materi RUU Desa berdasarkan dinamika ide-ide kebijakan yang berkembang dan terus mewarnai perjalanan pembahasan RUU. Dan Keempat, para tenaga ahli DPR dari luar yaitu: (1) Dr.Zain Badjeber (ahli konstitusi dan pernah menjadi anggota DPR RI sebanyak 6 kali periode), (2) Yando Zakaria (akademisi), Sutoro Eko (sosiolog), Dr. Suhirman (ITB) adalah individu dari luar lembaga DPR dan pemerintah yang berperan sebagai agen utama perubahan kebijakan yang bersumber dari alokasi APBN pada UU No.6 Tahun 2014. Peran mereka adalah menyampaikan ide-ide kebijakan kepada para anggota Pansus, anggota Panja dan juga pemerintah pada saat pembahasan kebijakan, sehingga dapat mempengaruhi pengambilan keputusan atas kebijakan tersebut.

4. Waktu sebagai elemen kunci dalam proses
perubahan kebijakan

Waktu (periode) kejadian merupakan elemen kunci dalam proses perubahan kebijakan kebijakan pendapatan desa yang bersumber dari alokasi APBN. Periode awal reformasi (1999) menjadi titik awal perubahan mendasar kebijakan pada UU No.22 Tahun 1999 yaitu perubahan kebijakan sumber pendapatan desa dari yang mengedepankan prinsip keseragaman sebagaimana diatur pada UU No. 5 Tahun 1979 menjadi kebijakan sumber pendapatan desa yang mengedepankan prinsip keanekaragaman. Selain itu, juga merupakan periode awal penggabungan pengaturan kebijakan dari yang semula diatur tersendiri melalui UU tentang desa (UU No. 5 Tahun 1979) menjadi diatur melalui UU tentang pemerintahan daerah (UU No.22 Tahun 1999). Namun demikan, waktu perumusan kebijakan yang kurang lebih hanya 3 bulan (4 Ferbruari 1999-21 April 1999) nampak terlalu singkat sehingga pembahasan kebijakan sumber pendapatan desa tidak terlalu menjadi perhatian dari pemerintah dan DPR. Begitupun dengan waktu perumusan kebijakan sumber pendapatan desa pada UU No.32 Tahun 2004 selama kurang lebih bulan (9 Ferbruari 2004-15 Oktober 2004) juga nampak terlalu singkat dan pembahasan kebijakan sumber pendapatan desa juga tidak terlalu menjadi fokus perhatian dari pemerintah dan DPR.

Selanjutnya periode tahun 2014 menjadi periode awal diaturnya kembali kebijakan sumber pendapatan desa dari yang sebelumnya diatur melalui UU tentang pemerintahan daerah (UU No.22 Tahun 1999 dan UU No.32 Tahun 2004) menjadi diatur tersendiri melalui UU tentang Desa (UU No.6 Tahun 2014) dengan mengedepankan prinsip rekognisi dan subsidiaritas. Momentum waktu yaitu satu dasawarsa implementasi UU No.32 Tahun 2004 dan menjelang akhir masa pemerintahan rezim Presiden Susilo Bambang Yudhoyono dan menjelang masa Pemilu 2014 menjadi momentum penting yang mendorong adanya kesepakatan politik antara pemerintah dan DPR untuk memecah UU No.32 Tahun 2004 menjadi tiga UU salah satunya adalah UU tentang Desa. Momentum tersebutlah yang kemudian juga mendorong pemerintah dan DPR melakukan pembahasan yang lebih intensif terhadap kebijakan pendapatan desa yang bersumber dari alokasi APBN yang belum pernah diatur sebelumnya bahkan menjadi daya tarik dari berbagai kalangan terutama elemen desa (kepala desa, perangkat desa, dan masyarakat desa) yang kemudian juga secara intesif menyampaikan ide-ide kebijakan kepada DPR dan pemerintah melalui kegiatan rapat dengar pendapat maupun aksi-aksi demonstrasi. Menurut Ketua Rapat Paripurna (Drs. Priyo Budi Santoso) bahwa RUU tentang desa telah dibahas melewati 9 kali masa persidangan dan baru selesai saat ini melalui proses yang sangat letih, melelahkan dan sedikit ruwet. Lebih lanjut Khatibul Umam Wiranu M.Hum pada saat yang sama juga menyatakan bahwa pembahasan UU selama 9 kali masa persidangan merupakan bagian tidak terpisahkan dari DPR tahun 1999-2004 yang mengusulkan UU Pembangunan Desa dan pemerintah tahun 1999-2004 yang mengusulkan UU tentang Pemerintahan Desa yang kemudian dari kedua usulan UU tersebut digabungkan menjadi UU Desa maka sudah cukup sempurna dan mengakomodasi seluruh keinginan masyarakat desa dan kepala desa. Dari waktu perumusan kebijakan selama kurang lebih 2 tahun (9 Januari 2012-15 Januari 2014) atau 3 kali masa persidangan DPR tahun 2009-2014, nampak adanya intesitas pembahasan yang relatif cukup lama antara pemerintah dan DPR terhadap kebijakan 
tersebut. Dengan kata lain, kebijakan pendapatan desa yang bersumber dari alokasi APBN pada masa tersebut nampak menjadi fokus Dari hasil identifikasi terhadap keempat hal tersebut dapat diketahui bahwa telah terjadi perubahan kebijakan pendapatan desa yang bersumber dari alokasi APBN (Dana Desa) pada masa Reformasi (1999-2015) dimana kebijakan pendapatan desa yang bersumber dari alokasi APBN (Dana Desa) pada UU No.6 Tahun 2014 adalah kebijakan baru yang ditetapkan oleh pemerintah untuk menggantikan kebijakan yang sudah ada sebelumnya yaitu kebijakan sumber pendapatan desa pada UU No.22 Tahun 1999 yang berbentuk bantuan pemerintah dan kebijakan sumber pendapatan desa yang berbentuk bantuan keuangan pemerintah pada UU No.32 Tahun 2004. Proses perubahan kebijakan tersebut terjadi pada tingkat perubahan ketiga yaitu perubahan paradigma kebijakan dimana dari awal masa reformasi (1999) ide dasar dan cara pandang dari rezim pemerintahan Presiden B.J Habibie terhadap tujuan kebijakan pendapatan desa yang berbentuk bantuan pemerintah pada UU No.22 Tahun 1999 dinilai tanpa dasar asas yang jelas begitupun dengan ide dasar dan cara pandang dari rezim pemerintahan Presiden Megawati Soekarno Putri (2004) terhadap tujuan kebijakan pendapatan desa yang berbentuk bantuan keuangan pemerintah pada UU No.32 Tahun 2004 namun demikian sifat perubahan kebijakannya cenderung mengalami kemajuan. Pada UU No.22 Tahun 1999 bentuk bantuan pemerintah tidak jelas ketersediaannya karena tidak ada rumusan yang eksplisit dan jelas tentang sumber anggaran, besaran dan cara pengalokasian, penyaluran dan penggunaannya dan kemudian pada UU No.32 Tahun 2004 berubah pengaturannya menjadi lebih eksplisit dan jelas rumusan tentang sumber anggaran bantuan keuangan pemerintah yaitu dari APBN tetapi tidak ada rumusan yang eksplisit dan jelas tentang besaran dan cara pengalokasian, penyaluran dan penggunaannya. Dalam implementasinya kebijakan sumber pendapatan desa yang berbentuk bantuan keuangan pemerintah dari tahun 1999 hingga tahun 2013 diwadahi dalam bentuk program pembangunan seperti PPK, PNPM dan program berbasis desa yang disalurkan melalui berbagai kementrian/lembaga pemerintah.

Kemudian ide dasar dan cara pandang dari tujuan kebijakan pendapatan desa yang bersumber dari alokasi APBN pada akhir pemerintahan rezim Presiden Susilo Bambang Yudhoyono (2014) berubah dengan mendasarkan pada asas rekognisi dan subsidiaritas yang kemudian pengaturan kebijakan sumber pendapatan desa dalam bentuk bantuan keuangan pemerintah dihilangkan dan dirumuskan dengan lebih eksplisit dan jelas yaitu sumber pendapatan desa dari alokasi APBN dengan ketersediaan yang jelas yaitu bersumber dari belanja pusat dengan mengefektifkan program yang berbasis desa secara merata dan berkeadilan, dengan besaran

${ }^{2}$ Hasil wawancara pada tanggal 17 November 2017 alokasi anggaran sebesar $10 \%$ dari dan diluar dana transfer daerah (on top) secara bertahap dan dihitung berdasarkan jumlah desa dan cara pengalokasian anggaran dengan memperhatikan jumlah penduduk, angka kemiskinan, luas wilayah, dan tingkat kesulitan geografis, penyaluranan kepada desa dan desa adat ditransfer melalui APBD kabupaten/kota dan penggunaannya adalah untuk membiayai penyelenggaraan pemerintahan, pembangunan, serta pemberdayaan masyarakat dan kemasyarakatan.

Berkaitan dengan cara pandang dari ketiga rezim pemerintahan tersebut, Kepala Sub Direktorat Fasilitasi Pendapatan dan Transfer Dana Desa ${ }^{2}$ berpendapat bahwa sebenarnya tidak ada perubahan yang signifikan dari rezim pemerintahan Presiden BJ Habibie dan Presiden Megawati Soekarno Putri dimana UU No.22 Tahun 1999, PP No.76 Tahun 2001, UU No.32 Tahun 2004 dan PP No.72 Tahun 2005 memiliki cara pandang yang sama yaitu negara memandang desa dari sisi keuangan sama sekalipun tidak secara eksplisit tetapi bantuan pemerintah dan bantuan keuangan pemerintah itu sama persis dalam bentuk program dari kementrian/lembaga, sedangkan perubahan signifikan itu nampak dari UU No.32 Tahun 2004 ke UU No.6 Tahun 2014 pada akhir masa rezim Pemerintahan Presiden Susilo Bambang Yudhoyono dan awal masa rezim pemeritahan Presiden Joko Widodo dimana belum pernah dibayangkan sebelumnya telah memotong semua sejarah UU sejak UU No.1 Tahun 1945 dan paling revolusioner sehingga paling banyak tafsirannya. Hal senada juga disampaikan oleh pengamat kebijakan keuangan desa IPDN ${ }^{3}$ yang menyatakan pendapat bahwa di dalam semua kebijakan tentang desa terutama pasalpasal yang mengatur tentang keuangan desa semuanya sebenarnya memberikan ruang bahwa desa mempunyai pendapatan baik di UU No.5 Tahun 1979, UU No. 22 Tahun 1999 dimana desa sebagai tuntutan reformasi (desentralisasi dan demokratisasi), begitupun UU No. 32 Tahun 2004 dengan lahirnya PP No.72 tahun 2005 sudah mulai ada penguatan desa terutama keuangan desa yang bersumber dari ADD yang pada UU No.22 Tahun 1999 dan UU No.32 Tahun 2004 disebut dalam dana perimbangan keuangan yang diterima kabupaten/kota sebesar 10 \% untuk desa. Adapun di UU No.6 Tahun 2014 terlihat drastis sekali upaya memperkuat desa. Pada UU 5 tahun 1979 sebetulnya keuangan desa sudah mendapatkan support dari APBN walaupun sebutan, istilah, nomenklatur alokasi APBN bagi desa itu tidak ada, namanya Inpres Bangdes (Intruksi Presiden tentang Pembangunan Desa) sumbernya sama dari APBN, semua desa sama, waktu itu mulai dari Rp 7,5 juta pada tahun 80an sampai naik menjadi Rp 15 juta artinya sudah ada kebijakan dari pemerintah pusat untuk keuangan desa, kemudian UU No.22 Tahun 1999 itu memang tidak disebutkan secara rinci karena UU ini kan menggabungkan berbagai pengaturan dari otonomi

${ }^{3}$ Hasil wawancara pada tanggal 20 November 2017 
daerah, pemerintahan daerah dan desa yang sebelumnya diatur sendiri dalam UU No.5 Tahun 1979 dan begitu banyak peraturan menteri turunannya, walaupun tidak menyebutkan secara rinci sumber keuangan dari APBN bukan berarti pemerintah ataupun UU ini tidak memberikan ruang atau tidak memungkinkan untuk bantuan itu, jadi namanya UU perlu dibuat luwes dan tidak secara detail sehingga bentuknya itu nomenklaturnya disebutkan diperaturan turunannya, bisa namanya ADD, seperti itu, sehingga sekalipun tidak disebutkan secara rinci spirit dan semangat UU No. 22 tahun 1999 cukup kuat. Tetapi memang di pemerintahan itu dari tahun ke tahun semakin menemukan bentuknya, seperti UU No. 6 Tahun 2014 ini adalah penyempurnaan menjadi lebih baik dan besarannya semakin besar seperti itu. Perubahannya ini sebenarnya adalah hasil penyempuranaan UU sebelumnya yang sebetulnya sudah memberikan ruang sekalipun tidak secara eksplisit.

\section{E. PENUTUP}

Berdasarkan hasil penelitian dapat ditarik kesimpulan bahwa perubahan kebijakan pendapatan desa yang bersumber dari alokasi APBN pada masa Reformasi (1999-2015) terjadi pada tingkat perubahan ketiga (perubahan paradigma kebijakan) dari rezim pemerintahan Presiden B.J Habibie dan Presiden Megawati Soekarno Putri melalui konsep bantuan pemerintah dari APBN dengan asas desentralisasi dan keanekaragaman ke rezim pemerintahan Presiden Susilo Bambang Yudhoyono dengan konsep alokasi 10\% dari APBN dengan asas rekognisi dan subsidiaritas. Alasan perubahan kebijakan tersebut antara lain karena adanya:

1. Adanya perubahan ide dan kepentingan dari rezim pemerintahan yang berkuasa pada masa reformasi (1999-2015) yaitu dari rezim pemerintahan Presiden BJ. Habibie, rezim pemerintahan Presiden Megawati Soekarno Putri dan rezim pemerintahan Presiden Susilo Bambang Yudhoyono terhadap tujuan kebijakan pendapatan desa yang bersumber dari alokasi APBN,

2. Adanya peran dari lembaga pemerintah yaitu Kementrian Dalam Negeri selaku lembaga eksekutif dan DPR selaku lembaga legislatif sebagai dua lembaga yang paling menonjol perannya sebagai arena instrument kebijakan pendapatan desa yang bersumber dari alokasi APBN. Dua lembaga tersebut sangat berpengaruh dalam menerjemahkan ide-ide kebijakan yang berkembang menjadi alternatif kebijakan hingga kemudian menjadi keputusan kebijakan pada UU,

3. Adanya peran individu sebagai agen utama perubahan kebijakan yaitu pada UU No.22 Tahun 1999 adalah H. Syarwan Hamid selaku Menteri Dalam Negeri, kemudian pada UU No.32 Tahun 2004 adalah Oentarto Sindung Mawardi selaku Direktur Jenderal Otonomi Daerah, Departemen Dalam Negeri. Sementara itu, pada UU No.6 Tahun 2014 antara lain Gamawan Fauzi selaku Menteri
Dalam Negeri, Drs. Ahmad Muqowam selaku Ketua Pansus RUU Desa, Budiman Sudjatmiko M.Sc., M.Phil (F-PDI P) selaku Ketua Panja dan para tenaga ahli DPR dari luar yaitu: Dr.Zain Badjeber (ahli konstitusi dan pernah menjadi anggota DPR RI sebanyak 6 kali periode), Yando Zakaria (akademisi), Sutoro Eko (sosiolog), Dr. Suhirman (ITB), dan

4. Waktu (periode) kejadian sebagai elemen kunci dalam proses perubahan kebijakan. Periode awal reformasi (1999) menjadi titik awal perubahan mendasar pengaturan pada sumber pendapatan desa UU No.22 Tahun 1999 yang mengedepankan prinsip keanekaragaman dan asas desentralisasi dan periode awal penggabungan pengaturan desa dari yang semula diatur tersendiri melalui UU tentang desa (UU No. 5 Tahun 1979) menjadi diatur melalui UU tentang pemerintahan daerah (UU No.22 Tahun 1999). Selanjutnya periode tahun 2014 menjadi periode awal diaturnya kembali pengaturan desa melalui UU tersendiri tentang Desa (UU No.6 Tahun 2014) dengan perubahan pada prinsip pengaturan sumber pendapatan desa yaitu mengedepankan prinsip rekognisi dan subsidiaritas. Selain itu tahun 2014 sebagai momentum waktu yaitu satu dasawarsa implementasi UU No.32 Tahun 2004 dan menjelang akhir masa pemerintahan rezim Presiden Susilo Bambang Yudhoyono serta menjelang masa Pemilu 2014 menjadi momentum penting yang mendorong adanya kesepakatan politik terhadap ditetapkannya kebijakan pendapatan desa yang bersumber dari alokasi APBN.

Dari kesimpulan penelitian tersebut dapat diketahui bahwa perubahan kebijakan pendapatan desa yang bersumber dari alokasi APBN (Dana Desa) pada masa Reformasi (1999-2015) menunjukkan kinerja perubahan kebijakan yang cenderung maju dari UU No. 22 Tahun 1999 hingga UU No.6 Tahun 2014 terutama dalam hal ide dan kepentingan, peran lembaga, peran individu dan waktu (periode) sebagai elemen kunci yang mempengaruhi perubahan tujuan kebijakan tersebut.

\section{DAFTAR PUSTAKA}

\section{BUKU}

Budiardjo, Mirriam. 2015. Dasar-Dasar Ilmu Politik. Jakarta: PT. Gramedia Pustaka Utama.

Bungin, Burhan. 2014. Penelitian Kualitatif Komunikasi, Ekonomi, Kebijakan Publik, dan Ilmu Sosial Lainnya Edisi Kedua. Jakarta: Prenada Media Group.

Creswell, John. W. 2015. Penelitian Kualitatif dan Desain Riset-Memilih dari Lima Pendekatan. Yogyakarta: Pustaka Pelajar.

Creswell, John W.2016. Research Design Pendekatan Metode Kualitatif, Kuantitatif dan Campuran Edisi Keempat. Yogyakarta: Pustaka Pelajar 
Dudley, Geoffrey dan Jeremy Richardson. 2000. Why Does Policy Change? Lesson from Britis Transport Policy 1945-99. London: Routledge.

Eko, Sutoro. 2015. Regulasi Baru, Desa Baru (Ide, Misi dan Semangat UU Desa). Jakarta: Kementrian Desa, PDT dan Transmigrasi.

Kay, Adrian. 2006. The Dynamic of Public Policy Theory and Evidence. USA: Edward Elgar Publishing.

Moran, Michael, dkk. 2006. The Oxford Handbook of Public Policy. Oxford: Oxford University Press.

Nugroho, Riant. 2014. Public Policy. Jakarta: PT. Elex

Multimedia

Nugroho, Riant. 2015. Kebijakan Publik di NegaraNegara Berkembang. Yogyakarta: Pustaka Pelajar.

Nugraheni, Ismi Dwi A.2009. Kebijakan Publik Pro Gender. Surakarta: UNS Press, 2009), hlm 130.

Parsons, Wayne. 2011. Public Policy: Pengantar Teori \& Praktik Analisis Kebijakan. Jakarta:Kencana.

Silalahi, Uber. 2009. Metode Penelitian Sosial.

Bandung: PT.Refika Aditama

Suharto, Didik G. 2016. Membangun Kemandirian Desa (Perbandingan UU No.5/1979, UU No.22/1999, \& UU No.32 Tahun 2004, serta Perspektif UU No.6/2014). Yogyakarta: Pustaka Pelajar.

Wahidin, Samsul. 2013. Hukum Pemerintahan Daerah, Pendulum Otonomi Daerah dari Masa ke Masa. Yogyakarta: Pustaka Pelajar.

Winarno, Budi. 2012. Kebijakan Publik Teori, Proses dan Studi Kasus. Jakarta:CAPS.

Sekretariat Jenderal DPRRI. 2000. Proses Pembahasan Rancangan Undang-Undang Tentang Pemerintahan Daerah. Jakarta: Sekretariat Jenderal DPR RI.

\section{JURNAL DAN PENELITIAN}

Baumgartner, F. R. 2013. Ideas and Policy Change. Governance, 26: 239-258. doi:10.1111/gove.12007.

Cerna, Lucie. 2013. The Nature of Policy Change and Implementation: A Review of Different Theoretical Approaches. OECD: 4-17.

Eko, Sutoro. 2008. Masa Lalu, Masa Kini, dan Masa Depan Otonomi Desa. Workingpapaer/Eko/II/Februari/2008, Yogyakarta: Institute for Research and Empowerment (IRE). https:/www.scribd.com/doc/53228313/SutoroEko-Masa-Lalu-Masa-Kini-Otonomi-Desa diakses pada 30 Agustus 2016.

Wilson, Carter A. 2000. Policy Regime and Policy Change. Journal of Public Policy, Vol. 20, No. 3. (September-Desember 2000), hlm 247-274. Cambridge University. http://www.jstor.org/stable/4007691 Diakses: 21/05/2010 17:08
Hanipiah, Pipin. 2014. Zigzag Kebijakan Strate of the Art Ilmu Pemerintahan di Indonesia. Jurnal Agregrasi (Aksi Reformasi Government dalam Demokrasi), Volume 2, Nomor 1, Tahun 2014, hlm 141150. http://ip.unikom.ac.id/files/Agregasi/Jurnal \%20Agregasi\%20Volume\%202\%20tahun $\% 2020$ 14.pdf diakses pada 5 Juni 2017.

Pratiwi, Rianti dan Roekhudin. 2015. Implementasi Pengelolaan Keuangan Dana Desa yang Bersumber Dari APBN 2015 (Studi pada Desa Tunjungtirto Kecamatan Singosari, Kabupaten Malang),

http://jimfeb.ub.ac.id/index.php/jimfeb/article/do wnload/2990/2676 diakses pada 7 Maret 2017

KPK. 2015. Laporan Hasil Kajian Pengelolaan Keuangan Desa: Alokasi Dana Desa dan Dana Desa.

https://acch.kpk.go.id/id/component/bdthemes_s hortcodes/?view=download\&id=bd20cd6416656 c2a441659f4bb77ab diakses pada 27 April 2016.

Abidin, Muhammad Zainul. 2015. Tinjauan Atas Pelaksanaan Keuangan Desa dalam Mendukung Kebijakan Dana Desa. https://jurnal.dpr.go.id/index.php/ekp/article/vie w/156/100 diakses pada 7 Maret 2017.

Ismail, Muhammad, dkk. 2016. Sistem Akutansi Pengelolaan Dana Desa. Jurnal Ekonomi dan Bisnis. Volume XIX No. 2, Agustus 2016, http://ejournal.uksw.edu/jeb/article/download/33 6/pdf diakses pada 7 Maret 2017

Mongilala, Chrisye. 2016. Kajian Yuridis mengenai Pengelolaan dan pertanggungjawaban Dana Desa di Kabupaten Minahasa Selatan. Lex et Societatis, Vol. IV/No. 6/Juni/2016. http://ejournal.unsrat.ac.id/index.php/lexetsocieta tis/article/viewFile/12522/12094 diakses pada 7 Maret 2017

Aziz, Nyimas Latifah Letty. 2016. Otonomi Desa dan Efektivitas Dana Desa. http://ejournal.lipi.go.id/index.php/jpp/article/do wnload/575/480 diakes pada 7 Maret 2017.

Hasjimzoem, Yusnani. 2014. Dinamika Hukum Pemerintahan Desa. Fiat Justisia Jurnal Ilmu Hukum Volume 8 No.3, Juli-September 2014. http://download.portalgaruda.org/article.php?arti cle $=358769 \&$ val=6694\&title=DINAMIKA\%20 HUKUM\%20PEMERINTAHAN\%20DESA

Pusat Kajian Politik FISIP UI. 2016. Makalah Kebijakan Grand Design Tata Kelola Desa Yang Partisipatif, Adil dan Setara. Puskapol FISIP UI. http://www.puskapol.ui.ac.id/wpcontent/uploads/2016/06/MAKALAHKEBIJAKAN-TATA-KELOLADESA_PUSKAPOL-UI.pdf diakses pada 19 Oktober 2016.

Agusta, Ivanovich. 2014. Transformasi Desa Indonesia 2003-2025. http://www.perhepi.org/wpcontent/uploads/2014/11/Transformasi-Desa- 
Indonesia-2003-2025_Dr.-Ivanovich-Agusta.pdf diakses pada tanggal 19 Oktober 2017 